\title{
Variation of Mechanical Characteristics and Microstructural Evolution in AISI 316 Austenitic Stainless Steel Subjected to Long-Term Thermal Aging at Elevated Temperature*
}

\author{
C. S. Kim \\ Department of Materials Science and Engineering, Chosun University, Gwangju, Korea \\ chs2865@chosun.ac.kr
}

УДК 539.4

\section{Изменение механических характеристик и микроструктуры аустенитной нержавеющей стали AISI 316 при длительном термическом старении в условиях повышенной температуры}

\author{
С. С. Ким \\ Факультет материаловедения и машиностроения, Университет в Кванджу, Корея
}

\begin{abstract}
Исследована механическая деградация аустенитной нержавеющей стали AISI 316, которая применяется в качестве материала для сосудов давления легководного ядерного реактора $в$ первичной системе атомных электростаниий. Изучено влияние длительного старения на микроструктуру и механические характеристики. Длительные испытания на старение прерывались на различных стадиях, чтобы получить разные уровни деградации образцов. Образиь стали AISI 316 подвергались ускоренной термообработке при температуре $600^{\circ} \mathrm{C}$ вплоть до 10000 ч. При этом обнаружены зерна многоугольной формы с многочисленными двойниками отжига, большая часть из которых в течение длительного старения постепенно принимала округлую форму. При начальной деградации материала двойники распределялись равномерно в большинстве зерен и после длительного старения в течение 10000 ч исчезали. Дельта-феррит по границам зерна аустенита трансформируется в сигма-фазу и преципитаты $\mathrm{Cr}_{23} \mathrm{C}_{6}$ в течение длительного старения, при этом доля области на границе зерна увеличивается. Максимальная прочность отмечается при старении в течение 100 ч $u$ уменьшается вплоть до 1000 ч. При дальнейшем увеличении времени старения прочность повышается по сравнению с начальным состоянием. Однако удлинение и вязкость непрерывно уменьшаются, что свидетельствует об охрупчивании материала в течение длительного термического старения.
\end{abstract}

Ключевые слова: сталь AISI 316, длительное старение, деградация, механические характеристики, микроструктура.

Introduction. Structural components designed for severe high-temperature and highpressure environments of power and chemical plant facilities deteriorate during their operation, leading to growing safety and integrity concerns. In particular, damage to the structures at nuclear power plants could possibly be the cause of a radiation leak. Therefore, the safety evaluation or life assessment of such structures is required and considerably important, especially for structural materials used at a high temperature, which normally suffer microstructure degradation due to long-term exposure. To accurately

\footnotetext{
* Paper presented at the 5th Global Conference on Materials Science and Engineering (CMSE 2016, November 8-11, Taichung City, Taiwan). 
predict the integrity and remaining lifetime, the mechanical properties of the components that have degraded microstructures must be identified.

In the nuclear power plant (NPP) industry, various components and systems are operated under different service conditions. Austenitic AISI 316 stainless steel is widely used for high-temperature structures, such as pipes and steam turbines, due to its superior high-temperature strength, oxidation resistance, thermal conductivity and low thermal expansion $[1,2]$. However, the mechanical strength of these materials abruptly decreases during long-term service at a high temperature, resulting in the coarsening of intermetallic particles and lath subgrain broadening. The most common forms of damage to structural materials after prolonged exposure to high temperature and pressure are thermal aging, fatigue and creep. When these steels are exposed to high temperatures for a long period, however, they are generally subjected to mechanical softening [3-5]. As a result, the quantitative evaluation of the microstructure is crucial in assessing the lifetime and structural health monitoring of the components made of this type of steel. Therefore, in this study, the effect of long-term thermal aging on mechanical damage on AISI 316 austenite stainless steel was investigated at a high temperature to monitor the thermal degradation in nuclear plants.

1. Experimental Details. AISI 316 austenite stainless steel samples were prepared for the present study. The chemical compositions of the test materials were analyzed by inductively coupled plasma mass spectrometry (ICP-MS), as shown in Table 1 . The test specimens were isothermally aged at $600^{\circ} \mathrm{C}$ for $100,1000,5000$, and $10000 \mathrm{~h}$ in an electrical furnace. The thermally aged specimens were prepared with dimensions of $20 \times 20 \times 150 \mathrm{~mm}$. The test specimen preparation for light microscopy was carefully conducted because improperly prepared samples can lead to erroneous interpretations. Reasonably small-sized samples can be handled easily; therefore, in most cases, sectioning is required. Using a band saw, small-sized samples were prepared, and a low-speed diamond saw was used to reduce the deformation depth. Because it became increasingly difficult to keep the surface flat and obtain a high-quality polish over the entire surface, the test specimens were mounted with cold-mounting resins. The surface to be prepared was then abraded using a graded sequence of abrasives, starting with a coarse abrasive from 120- to 2000-grit silicon carbide grinding paper. After being ground to a 2000 -grit finish, the samples were polished to produce a flat, reasonably scratch-free surface with high reflectivity. Fine polishing was conducted with 1 - and $0.05-\mu \mathrm{m}$ alumina slurries. For most materials, the microstructure was revealed only by the application of an appropriate etching process. The chemical etching was achieved in reagents consisting of $80 \mathrm{ml} \mathrm{HCl}+13 \mathrm{ml}$ $\mathrm{HF}+7 \mathrm{ml} \mathrm{HNO}_{3}$ at $55^{\circ} \mathrm{C}$. To observe the fine precipitates along the grain boundary and grain interior, thin foils were prepared by twin jet polishing in a solution of $20 \%$ perchloric acid at $-15^{\circ} \mathrm{C}$ and $50 \mathrm{~V}$.

$\mathrm{T}$ a b 1 e 1

Chemical Composition of AISI 316 Steel (wt.\%)

\begin{tabular}{|c|c|c|c|c|c|c|c|c|c|c|c|c|c||}
\hline $\mathrm{C}$ & $\mathrm{Si}$ & $\mathrm{Mn}$ & $\mathrm{P}$ & $\mathrm{S}$ & $\mathrm{Mo}$ & $\mathrm{Ni}$ & $\mathrm{Cr}$ & $\mathrm{Cu}$ & $\mathrm{V}$ & $\mathrm{Ti}$ & $\mathrm{Nb}$ & $\mathrm{N}$ & $\mathrm{Fe}$ \\
\hline 0.02 & 0.35 & 1.58 & 0.032 & 0.001 & 2.47 & 10.82 & 17.41 & 0.43 & 0.06 & 0.001 & 0.02 & - & Bal. \\
\hline
\end{tabular}

The micro Vickers hardness was measured to determine the change in surface hardness with long-term aging. The surface was subjected to a standard pressure for a standard length of time by means of a pyramid-shaped diamond with a vertex angle of $136^{\circ}$. Ten hardness tests were conducted under a load of $1 \mathrm{~kg}$ and a hold time of $10 \mathrm{~s}$ based on ASTM E348. The hardness test was performed ten times for each test sample. The minimum and the maximum values were omitted, and then, the average of the remaining eight values was taken as the final hardness result of the samples. 
X-ray diffraction analysis was conducted to identify the crystallographic structures within AISI 316 stainless steel after mechanical polishing with $0.05-\mu \mathrm{m}$ alumina suspension. The geometry of an X-ray diffractometer is such that the sample rotates in the path of the collimated X-ray beam at an angle $\theta$, while the X-ray detector is mounted on an arm to collect the diffracted X-rays and rotates at an angle of $2 \theta$. The instrument used to maintain the angle and rotate the sample is termed a goniometer. The data were collected at $2 \theta$ from 30 to $80^{\circ}$. An X-ray diffractometer with monochromatic $\mathrm{Cu}-\mathrm{K} \alpha$ radiation at $40 \mathrm{kV}$ and $30 \mathrm{~mA}$ was used for the analysis. Electrolytic extraction was performed to identify the precipitates of AISI 316 stainless steel by dissolving the matrix in $10 \%$ hydrochloric acid in methanol at a voltage of $3 \mathrm{~V}$ for $12 \mathrm{~h}$. The tensile test was performed three times for each of the thermal aging conditions at the cross-head speed of $1 \mathrm{~mm} / \mathrm{min}$ at room temperature to evaluate the mechanical properties in accordance with ASTM E8. The specimen was prepared in a dog-bone shape with a gauge length of $50 \mathrm{~mm}$, a width of $6 \mathrm{~mm}$, and a thickness of $2 \mathrm{~mm}$.

The Feritscope was also applied to measure the fraction of delta-ferrite in the AISI 316 stainless steel with long-term aging. The Feritscope measures the ferrite content in austenitic steels according to the magnetic induction method. All magnetizable structure sections are measured, i.e., in addition to delta-ferrite, strain-induced martensite or other ferritic phases are measured. For the electron backscatter diffraction (EBSD) observation, the surfaces of the specimen were polished with $1-\mu \mathrm{m}$ diamond paste and a $0.05-\mu \mathrm{m}$ alumina slurry, followed by electropolishing using a mixture of $700 \mathrm{ml}$ of phosphoric acid and $300 \mathrm{ml}$ of distilled water, which was cooled in dry ice water and then stirred during polishing. The polishing conditions were 1.5-2 V for 5-10 min. A crystal orientation measurement was obtained with a TSL EBSD system with a field emission electron gun system.

2. Results and Discussion. Figure 1 shows the optical micrographs of AISI 316 austenite stainless steel at each long-term aging time. The polygonal grains and delta-ferrite along the grain boundaries are the typical microstructure of the AISI 316 stainless steel. The ferritic islands (dark black region) are in an elongated form and are parallel to the rolling direction in all microstructures. There are many annealing twins in grains and delta-ferrite that resemble small black spots on the grain boundaries, as shown in Fig. 1a. These annealing twins are typical in an fcc crystal structure with low stacking-fault energy materials [6]. As the aging time increases, the annealing twins disappear abruptly, and the grain shape changes from angular-shaped grains to round-shaped grains. There are few annealing twins for long-term aging, as shown in Fig. 1b and c.

The delta-ferrite is an unstable phase in stainless steel at the aging temperature of $600^{\circ} \mathrm{C}$; therefore, it transforms into a stable phase, i.e., the sigma phase, which forms predominantly out of delta-ferrite because the composition of delta-ferrite is similar to the sigma phase in high-alloyed $\mathrm{Cr}-\mathrm{Ni}$ steel. The sigma phase is undesirable because of the embrittlement of the matrix and the withdrawing of chromium from the matrix [7]. The consequence of this process is a drastic deterioration of the stability of the material against corrosion. When the sigma phase precipitates out of the delta-ferrite, austenite is also formed by the decrease in ferrite-forming elements $\mathrm{Cr}$ and Mo. The coarse sigma phase is clearly observed along the grain boundaries in Fig. $1 \mathrm{~b}$ and c. Table 2 shows the microstructural evolution of AISI 316 steel subjected to long-term aging. From the mechanical metallurgy perspective, the mechanical properties strongly depend on the microstructure of materials. The microstructural evolution investigated in this study during long-term aging included the twin fraction, grain size and aspect ratio of the grains. After $1000 \mathrm{~h}$ of aging, it is very difficult to observe annealing twins by OM analysis. Although the equilibrium grain size does not change during long-term aging, the aspect ratio of grains increases gradually. 
T a b 1 e 2

Microstructural Evolution of AISI 316 Steel Subjected to Long-Term Thermal Aging

\begin{tabular}{|c|c|c|c||}
\hline Aging (h) & Twin fraction $(\%)$ & Grain size $(\mu \mathrm{m})$ & Aspect ratio \\
\hline 0 & $63 \pm 5$ & $56 \pm 13$ & $0.56 \pm 0.12$ \\
\hline 100 & $60 \pm 3$ & $55 \pm 16$ & $0.60 \pm 0.08$ \\
\hline 1000 & 0 & $55 \pm 9$ & $0.61 \pm 0.10$ \\
\hline 5000 & 0 & $62 \pm 15$ & $0.63 \pm 0.10$ \\
\hline 10000 & 0 & $59 \pm 11$ & $0.64 \pm 0.09$ \\
\hline
\end{tabular}
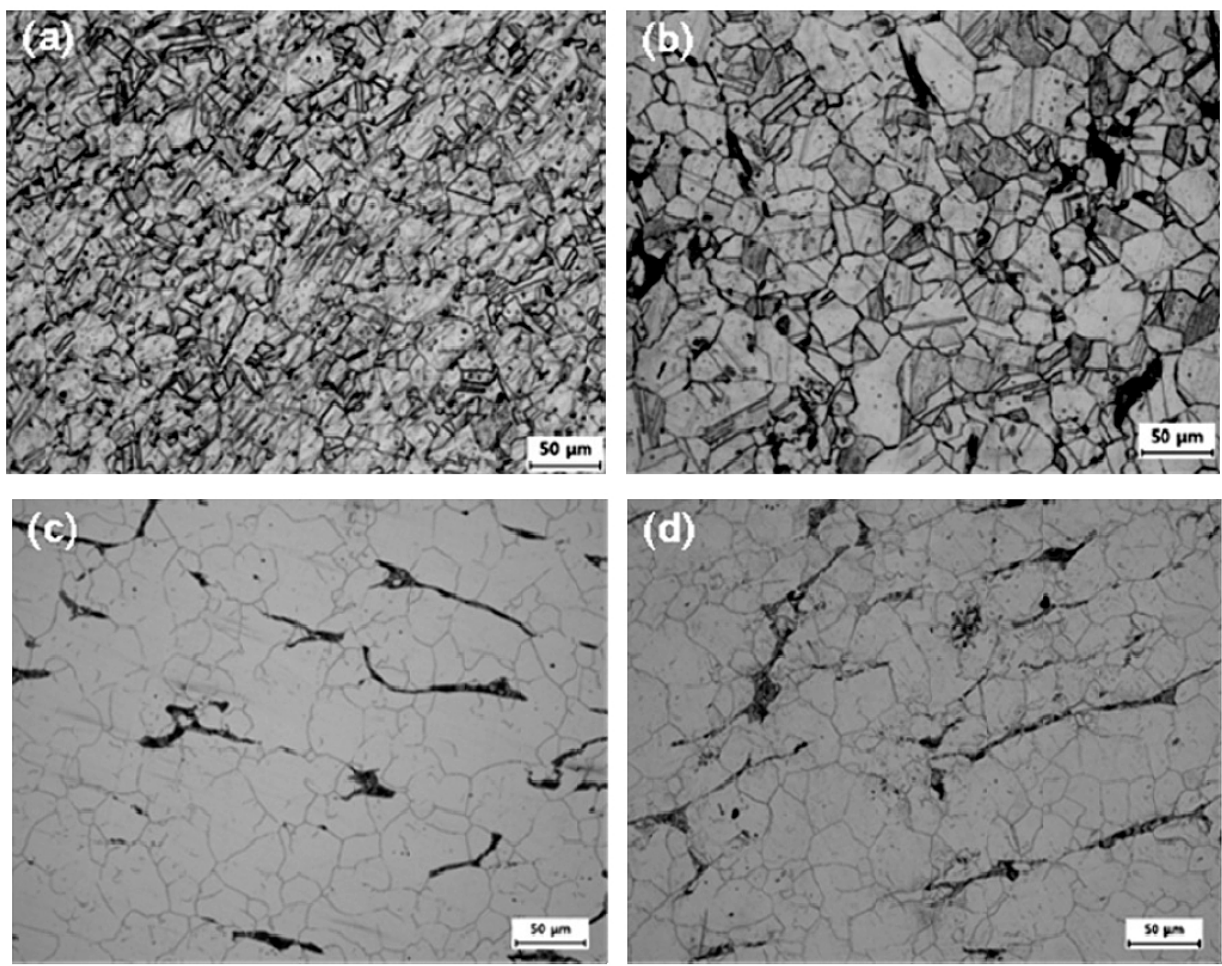

Fig. 1. Optical micrographs of AISI 316 austenite stainless steel at each long-term aging time: (a) 0 h, (b) $100 \mathrm{~h},(\mathrm{c}) 1000 \mathrm{~h}$, and (d) $10000 \mathrm{~h}$.

For a more precise observation of the surface micrographs, electron microscopy was used. As mentioned, the delta-ferrite transformation on the austenite grain boundaries was more clearly investigated via scanning electron micrographs, as shown in Fig. 2. Figure 2 depicts scanning electron micrographs of AISI 316 austenite stainless steel at each long-term aging time of 0 and $10000 \mathrm{~h}$. The delta-ferrite phases lie along the grain boundaries, and the equivalent size is approximately $6 \mu \mathrm{m}$. However, they are decomposed into sigma and $\mathrm{Cr}$ carbides, as shown in Fig. 2b [8]. The Laves phase $(\eta)$ is frequently found in austenitic stainless steels [9-11]. The $\mathrm{Fe}_{2} \mathrm{Mo}$ Laves phase was generated at $600^{\circ} \mathrm{C}$ in AISI 316 stainless steel before the precipitation of the sigma phase [12]. In this work, a Laves phase was observed in a decomposed area of delta-ferrite and at grain boundaries together with the sigma phase. Figure $2 \mathrm{c}$ and $\mathrm{d}$ are the magnified images of the rectangular area in Fig. 2a and b showing the generation of secondary precipitates known as Cr-rich $\mathrm{Cr}_{23} \mathrm{C}_{6}$ precipitates. 
$\mathrm{T}$ a b 1 e 3

Delta-Ferritic Volume Fraction in AISI 316 Steel

\begin{tabular}{|c|c|c|c||}
\hline Aging $(\mathrm{h})$ & SEM & Ferrite scope & XRD \\
\hline 0 & $2.80 \pm 0.10$ & $1.95 \pm 0.05$ & $2.30 \pm 0.10$ \\
\hline 100 & $2.70 \pm 0.06$ & $1.80 \pm 0.09$ & $1.70 \pm 0.10$ \\
\hline 1000 & $3.20 \pm 0.10$ & $1.00 \pm 0.03$ & $1.10 \pm 0.08$ \\
\hline 5000 & $3.10 \pm 0.08$ & $0.70 \pm 0.05$ & $0.50 \pm 0.02$ \\
\hline 10000 & $3.80 \pm 0.10$ & $0.50 \pm 0.02$ & 0 \\
\hline
\end{tabular}
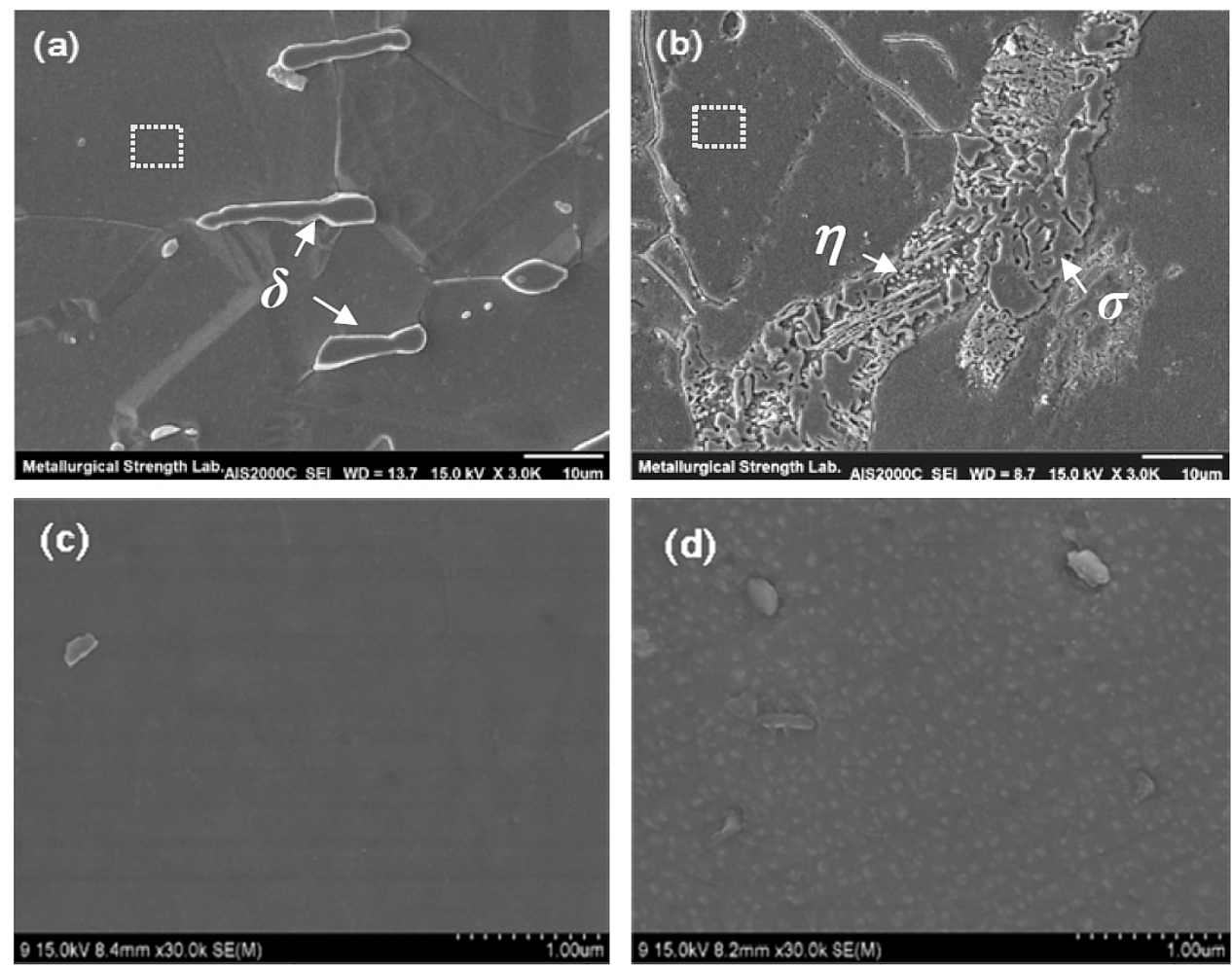

Fig. 2. Scanning electron micrographs of AISI 316 austenite stainless steel at each long-term aging time showing delta-ferrite decomposition along grain boundaries and generation of secondary precipitates: (a) $0 \mathrm{~h}$, (b) $10000 \mathrm{~h}$, (c) magnified image of rectangular area in (a), and (d) magnified image of rectangular area in (b).

Table 3 shows the delta-ferritic volume fraction in AISI 316 austenitic stainless steel subjected to long-term aging. The image analysis with SEM shows the delta-ferrite fraction increased up to $10000 \mathrm{~h}$. However, the delta-ferrite fraction analyzed by the ferrite scope and XRD decreased. This discrepancy originated from the decomposition of delta-ferrite during long-term aging. The image analysis does not consider the decomposition of delta-ferrite. As shown in the OM and SEM observations, the area of decomposition of delta-ferrite increased.

Figure 3 depicts electron backscatter diffraction micrographs of samples aged long term for $10000 \mathrm{~h}$, showing an orientation map of each phase in AISI 316 austenitic stainless steel. The orientation image shows the $\gamma$-matrix $(\gamma)$ and $\delta$-ferrite $(\alpha)$ on a grain boundary. 


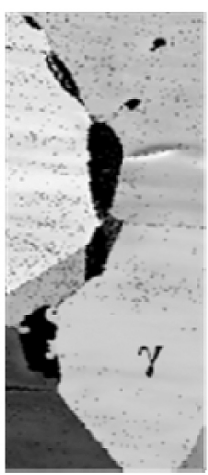

a

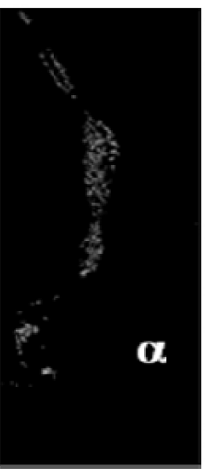

b

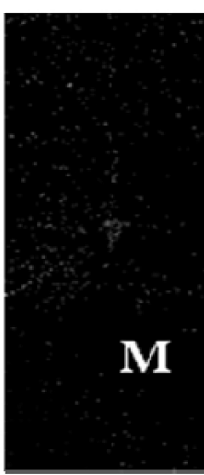

$\mathrm{C}$

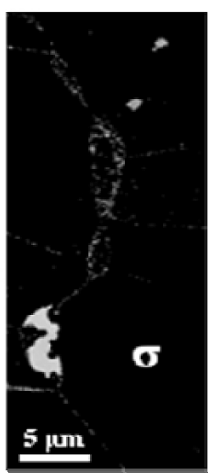

d

Fig. 3. Electron backscatter diffraction micrographs of long-term aged $10000 \mathrm{~h}$ AISI 316 specimen showing orientation map of each phase in AISI 316 austenitic stainless steel: (a) $\gamma$-matrix, (b) $\delta$ ferrite, (c) Cr-rich carbides, and (d) sigma $(\sigma)$ phase.

On the boundary, intermetallic $\mathrm{Cr}_{23} \mathrm{C}_{6}$ was introduced, denoted by $M$, and the sigma $(\sigma)$ phase was also generated on the boundary, indicating the spinodal decomposition of $\delta$ ferrite. As the aging time increased, the annealing twins were fully recovered, and the delta-ferrites were transformed into the sigma phases. Cr-rich carbides $(M)$ were present along the grain boundaries and the grain interiors. The sigma phase has a very important effect on the corrosive and mechanical properties of austenitic stainless steel [13, 14].

Figure 4 shows the typical TEM thin film images of AISI 316 austenite stainless steel at each long-term aging time, showing the triple point of grains. The Cr-depleted region, as indicated by arrows, was clearly shown along the grain boundaries of both specimens aging $100 \mathrm{~h}$ and those aging $5000 \mathrm{~h}$. Most of all, the width of the depleted region increased with thermal aging time, which was the sensitization of austenitic stainless steel subjected to long-term aging at elevated temperatures. This sensitization caused severe corrosion in austenitic stainless steel. In addition to the $\mathrm{Cr}$-rich $\mathrm{Cr}_{23} \mathrm{C}_{6}$ carbides, the coarsened Mo-rich $\mathrm{Fe}_{2} \mathrm{Mo}$ intermetallic phases (Laves) were observed with further aging.

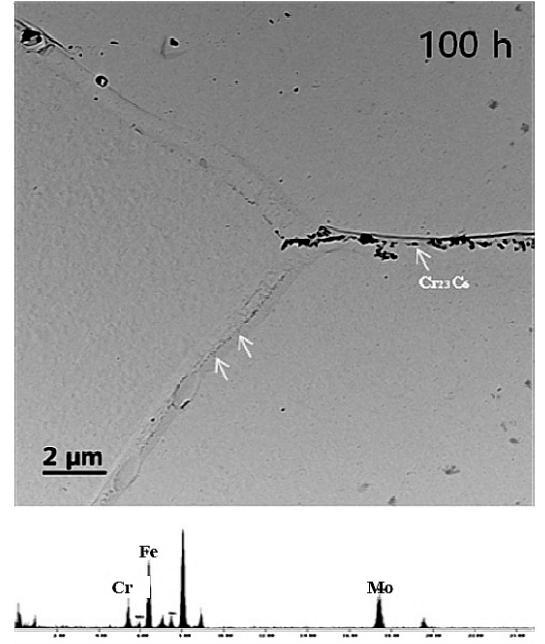

a

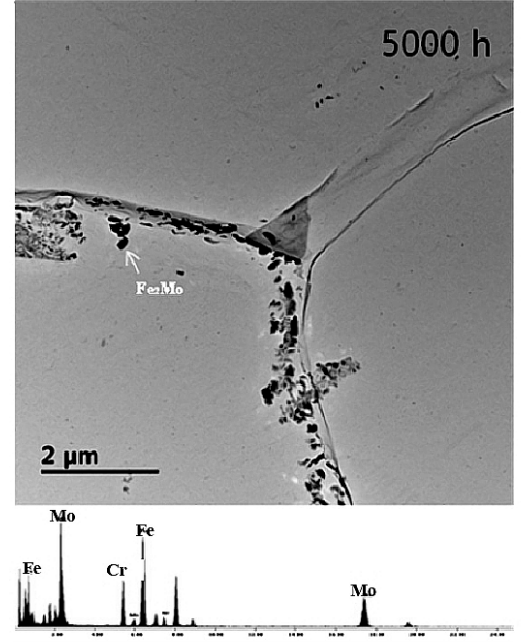

b

Fig. 4. TEM bright field images showing typical precipitates along grain boundary of AISI 316 specimen: (a) $100 \mathrm{~h}$ and (b) $5000 \mathrm{~h}$. 
Figure 5 shows the X-ray diffraction patterns of AISI 316 austenite stainless steel at each long-term aging time. As the aging time increased, the intensity of the diffraction peak of the delta-ferrite decreased due to decomposition during long-term aging. In this diffraction peak, it was possible to calculate the delta-ferrite fraction using direct comparison analysis [15]. The volume fraction of delta-ferrite was quantitatively measured as shown in Table 3.

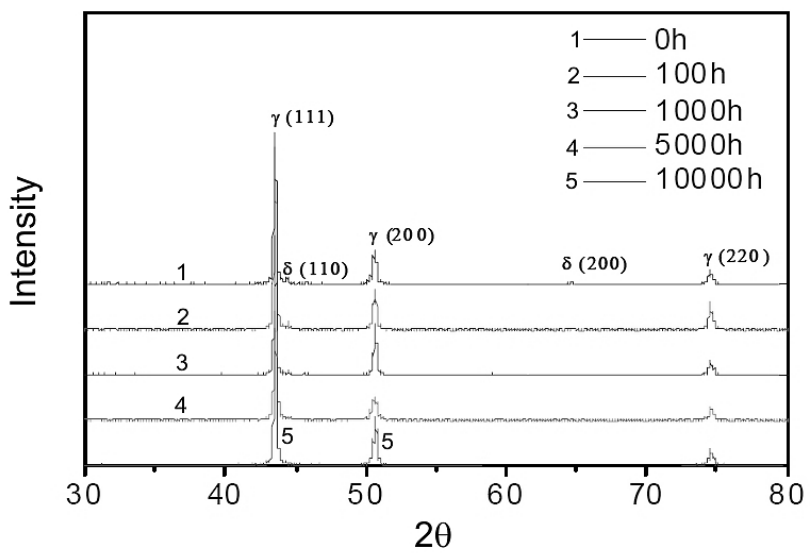

Fig. 5. X-ray diffraction profile of AISI 316 austenite stainless steel at each long-term aging time.

The precipitates played an important role in the mechanical strength mechanism. The electrolytic extraction was applied to identify the precipitates of AISI 316 stainless steel by dissolving the matrix. Figure 6 shows the typical X-ray diffraction profile of the extract residues of AISI 316 austenite stainless steel. The main precipitates were verified to be $\mathrm{M}_{23} \mathrm{C}_{6}$, which is well known as a Cr-rich carbide. The diffraction intensity of the sigma phase $\left(2 \theta=47^{\circ}\right)$ increased dominantly after $10000 \mathrm{~h}$ of aging due to delta-ferrite decomposition.

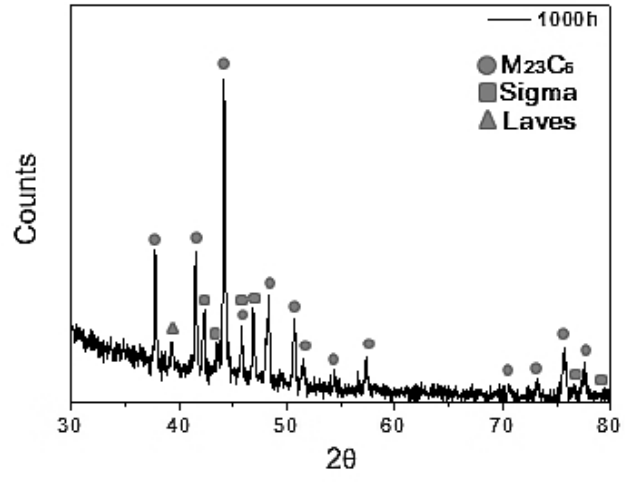

a

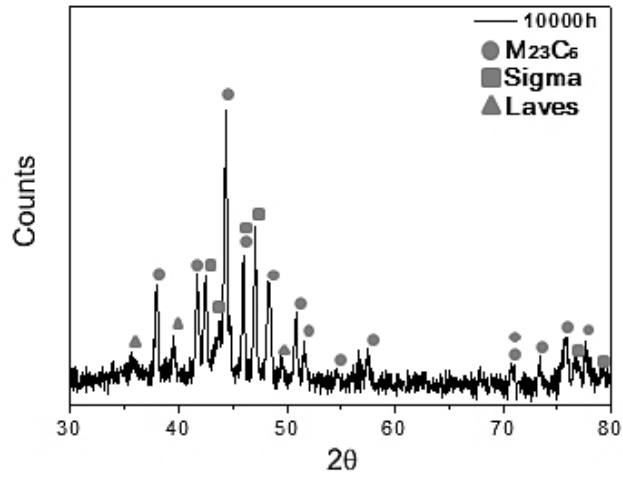

b

Fig. 6. X-ray diffraction profile of extract residues of AISI 316 austenite stainless steel: (a) $1000 \mathrm{~h}$ and (b) $10000 \mathrm{~h}$.

Figure 7 shows the variation in Vickers hardness as a function of aging time. As the aging time increased, the Vickers hardness increased abruptly at $100 \mathrm{~h}$ of aging and then decreased to the same level of the solution state. This increase in hardness originated from the nucleation of fine precipitation along the grain boundaries and the grain interior. After 


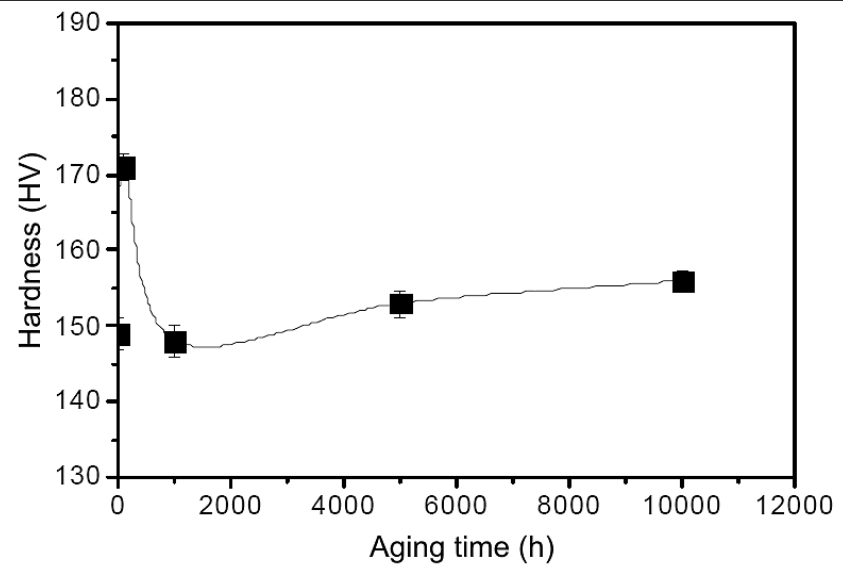

Fig. 7. Variation in Vickers hardness as a function of aging time.

the peak of hardness, the precipitates were coarsened, resulting in a decrease in hardness. For the long-term aging, the hardness increased continuously due to sigma phase generation during aging.

Figure 8 shows stress-strain curves of AISI 316 austenite stainless steel at each long-term aging time. It is not possible to observe a yield drop in this stainless steel. Therefore, in this study, the yield stress was measured using the $0.2 \%$ offset method. The AISI 316 austenitic stainless steel is a ductile material with a large elongation to the fracture. As the aging time increased, the elongation decreased, demonstrating the embrittlement of austenitic stainless steel during long-term aging.

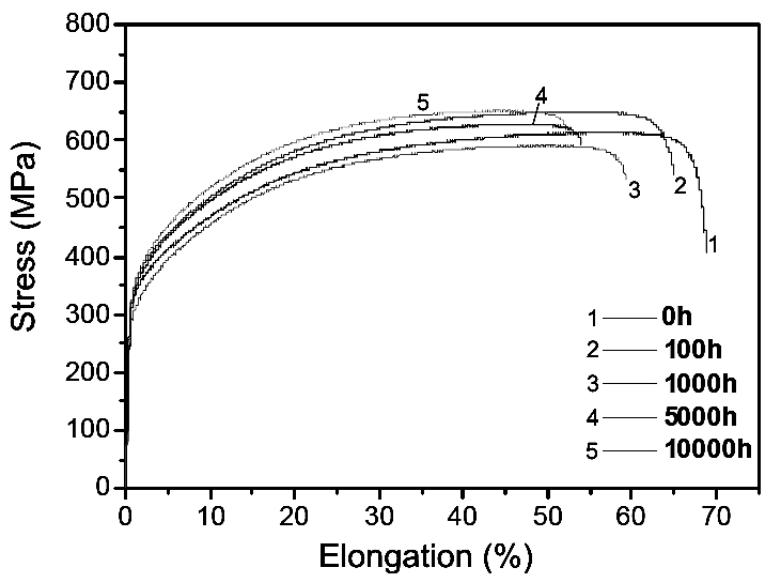

Fig. 8. Stress-strain curves of AISI 316 austenite stainless steel at each long-term aging time.

Table 4 shows the mechanical properties of AISI 316 austenitic stainless steel subjected to long-term aging. The elongation and toughness decreased continuously with aging time, i.e., the material underwent embrittlement during long-term aging. However, the yield strength and the ultimate tensile strength increased in the initial aging time of $100 \mathrm{~h}$, exhibiting the peak of strength. Subsequently, the strength decreased up to $1000 \mathrm{~h}$ of aging time, exhibiting a minimum of strength. After the aging time was prolonged to $10000 \mathrm{~h}$, it was clearly noticed that the strength increased consistently. This variation in tensile strength was in accordance with the hardness changes. 
$\mathrm{T}$ a b 1 e 4

Mechanical Properties of AISI 316 Steel Subjected to Long-Term Aging

\begin{tabular}{|c|c|c|c|c|}
\hline \hline Aging (h) & $\begin{array}{c}\text { Yield stress } \\
(\mathrm{MPa})\end{array}$ & $\begin{array}{c}\text { Ultimate stress } \\
(\mathrm{MPa})\end{array}$ & Elongation $(\%)$ & $\begin{array}{c}\text { Toughness } \\
\left(\mathrm{MJ} / \mathrm{m}^{2}\right)\end{array}$ \\
\hline 0 & 323 & 608 & 69 & 379 \\
100 & 340 & 646 & 65 & 379 \\
1000 & 288 & 590 & 59 & 313 \\
5000 & 321 & 627 & 54 & 304 \\
10000 & 332 & 650 & 52 & 303 \\
\hline
\end{tabular}
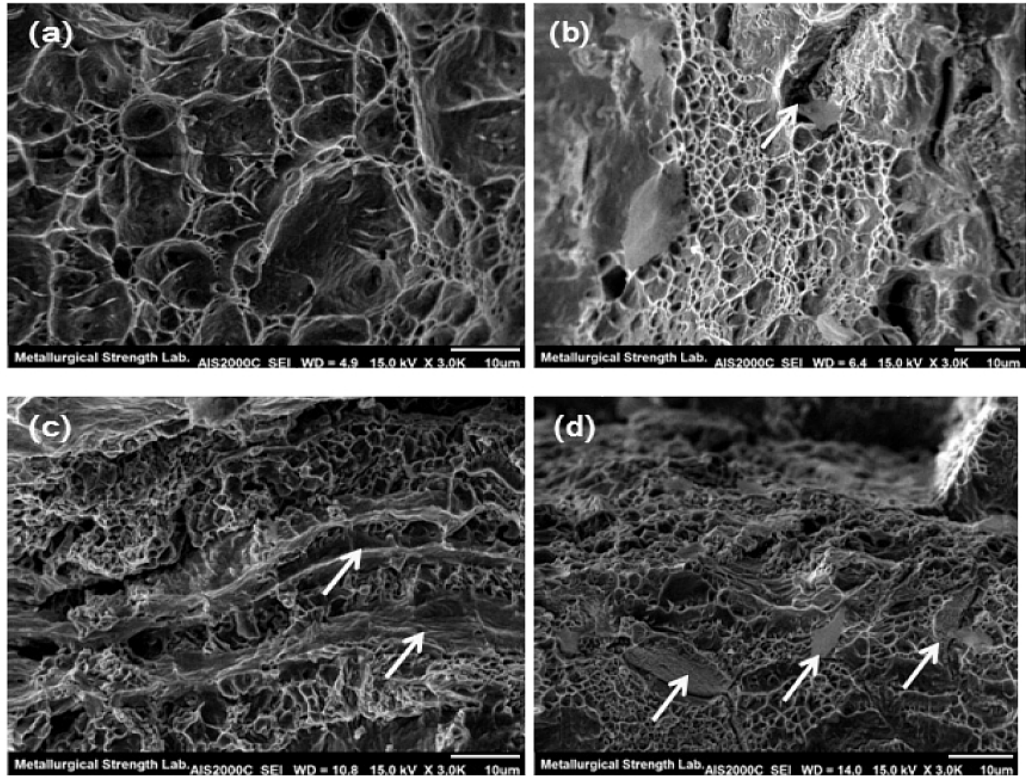

Fig. 9. Scanning electron micrographs of fracture surface of AISI 316 austenite stainless steel at each long-term aging time: (a) $0 \mathrm{~h}$, (b) $100 \mathrm{~h}$, (c) $1000 \mathrm{~h}$, and (d) $10000 \mathrm{~h}$.

Figure 9 shows scanning electron micrographs of the fracture surface of AISI 316 austenite stainless steel at each long-term aging time. The dimple is a general phenomenon of the ductile fracture of materials. AISI 316 austenite stainless steel shows a typical fractograph of ductile fracture mode. As the aging time increased, the dimple size decreased, resulting in decreases of elongation and toughness during long-term aging. In particular, the site of delta-ferrite decomposition is clearly observed, as denoted by arrows. These interfaces between the decomposed sigma phase and the austenite matrix might be a crack propagation path and a crack nucleation site due to incoherent characteristics [16]. Therefore, the sample shows a brittle fracture mode with a thermal aging time increase.

Conclusions. AISI 316 austenite stainless steel showed polygonal-shaped grains with many annealing twins that gradually tended to become more circular-shaped grains during long-term aging. In the initial material degradation, the twins were distributed uniformly within most grains, but they all recovered and disappeared after the prolonged 10000-hour aging time. Delta-ferrite along austenitic grain boundaries transformed into sigma phases and $\mathrm{Cr}_{23} \mathrm{C}_{6}$ precipitates during long-term aging, and the area fraction on the grain boundary increased. The peak yield and ultimate tensile strength appeared at the 100-hour aging time and then decreased up to $1000 \mathrm{~h}$, exhibiting a minimum of strength. For further aging time, the strength increased to a level higher than that of the initial state. However, elongation 
and toughness decreased continuously, demonstrating the material embrittlement during long-term aging. The typical fractograph of AISI 316 austenite stainless steel shows ductile fracture mode. As the aging time increased, the dimple size decreased, resulting in decreases of elongation and toughness. These interfaces between the decomposed sigma phase and the austenite matrix might be a crack nucleation and propagation site due to incoherent characteristics.

Acknowledgments. This research was supported by the National Research Foundation of Korea (NRF) Grant funded by the Korean Government (NRF-2013M2A2A9043241).

\section{Резюме}

Досліджено механічну деградацію аустенітної нержавіючої сталі AISI 316, яка використовується як матеріал для посудин тиску легководного ядерного реактора в первинній системі атомних електростанцій. Вивчено вплив тривалого старіння на мікроструктуру і механічні характеристики. Тривалі випробування на старіння переривались на різних стадіях, щоб отримати різні рівні деградації зразків. Зразки сталі AISI 316 піддавали прискореній термообробці за температури $600^{\circ} \mathrm{C}$ аж до 10000 годин. Виявлено зерна багатокутної форми з численними двійниками відпалу, більшість 3 яких протягом тривалого старіння поступово приймала округлу форму. При початковій деградації матеріалу двійники розподілялись рівномірно в більшості зерен і після тривалого старіння протягом 10000 годин зникали. Дельта-ферит по границі зерна аустеніту трансформується в сигма-фазу і преципітати $\mathrm{Cr}_{23} \mathrm{C}_{6}$ протягом тривалого старіння, при цьому частка області на границі зерна збільшується. Максимальна міцність має місце при старінні протягом 100 годин і зменшується аж до 1000 годин. При подальшому збільшенні часу старіння міцність зростає порівняно з початковим станом. Однак подовження і в'язкість неперервно зменшуються, що свідчить про окрихчення матеріалу протягом тривалого термічного старіння.

1. T. Koutsoukis, A. Redjaimia, and G. Fourlaris, "Phase transformations and mechanical properties in heat treated superaustenitic stainless steels," Mater. Sci. Eng. A, 561, 477-485 (2013).

2. S. Chunwen, H. Rob, Q. Wei, and Y. Sing, "Progress in corrosion resistant materials for supercritical water reactors," Corros. Sci., 51, 2508-2523 (2009).

3. C. S. Kim, "Creep characterization in advanced heat-resistant steel using ultrasonic nonlinearity technique," Mater. Trans., 53, 2028-2033 (2012).

4. A. Mortezaie and M. Shamanian, "An assessment of microstructure, mechanical properties and corrosion resistance of dissimilar welds between Inconel 718 and $310 \mathrm{~S}$ austenitic stainless steel,” Int. J. Pres. Ves. Pip., 116, 37-46 (2014).

5. C. S. Kim and K. Y. Jhang, "Acoustic nonlinearity of a laser-generated surface wave in a plastically deformed aluminum alloy," Chinese Phys. Lett., 29, 120701-1 (2012).

6. D. P. Field, L. T. Bradford, M. M. Nowell, and T. M. Lillo, "The role of annealing twins during recrystallization of Cu," Acta Mater., 55, 4233-4241 (2007).

7. I. Zucato, M. C. Moreira, I. F. Machado, and S. M. G. Lebrão, "Microstructural characterization and the effect of phase transformations on toughness of the UNS S31803 duplex stainless steel age treated at $850^{\circ} \mathrm{C}$," Mater. Res., 5, 385-389 (2002).

8. S. A. David, J. M. Vitek, and D. J. Alexander, "Embrittlement of austenitic stainless steel welds," J. Nondestruct. Eval., 15, 129-136 (1996).

9. M. P. Sello and W. E. Stumpf, "Laves phase embrittlement of the ferritic stainless steel type AISI 441," Mater. Sci. Eng. A, 527, 5194-5202 (2010). 
10. G. Sasikala, S. K. Ray, and S. L. Mannan, "Kinetics of transformation of delta ferrite during creep in a type $316(\mathrm{~N})$ stainless steel weld metal," Mater. Sci. Eng. A, 359, 86-90 (2003).

11. A. F. Padilha, D. M. Escriba, E. Materna-Morris, et al., "Precipitation in AISI $316 \mathrm{~L}(\mathrm{~N})$ during creep tests at 550 and $600^{\circ} \mathrm{C}$ up to 10 years," J. Nucl. Mater., 362, 132-138 (2007).

12. M. Minami, H. Kimura, and Y. Ihara, "Microstructural changes in austenitic stainless steels during long-term aging," Mater. Sci. Technol., 2, 795-806 (1986).

13. C. C. Hsieh and W. Wu, "Overview of intermetallic sigma $(\sigma)$ phase precipitation in stainless steels," ISRN Metallurgy, 2012, 732471-1 (2012).

14. L. Tian, Q. H. Xiao, H. K. Xiu, and Z. L. Dian, "Effect of the sigma phase on the mechanical properties of a cast duplex stainless steel during the ageing treatment at $850^{\circ} \mathrm{C}$," Adv. Mater. Res., 684, 325-329 (2013).

15. H. S. Zhao, X. Zhu, W. Li, et al., "Austenite stability for quenching and partitioning treated steel revealed by colour tint-etching method," Mater. Sci. Technol., 30, 10081013 (2014).

16. K. W. Chan and S. C. Tjong, "Effect of secondary phase precipitation on the corrosion behavior of duplex stainless steels," Materials, 7, 5268-5304 (2014).

Received 30. 08. 2016 